have shown, the rat is rather sensitive to the influence of such cues and they often take precedence over intra-maze stimuli.

One possible disadvantage of the present apparatus should be mentioned. A few Ss in the SOW group of each experiment were observed to strenuously oppose box withdrawal throughout training by wedging themselves into the corner between the fixed end wall and the moving floor and side walls. These Ss seldom avoided. Many other Ss displayed such resistance on early trials, but abandoned this behavior as they began to avoid. It is possible that the elimination of this maladaptive behavior would result in performance more closeiy approximating that obtained with unautomated one-way avoidance tasks.

\section{REFERENCES}

BAUM, M. An automated apparatus for the avoidance training of rats. Psychological Reports, 1965, 16, 1205-1211.

BAUM, M., \& BOBROW, S. A. An automated analogue of the one-way Miller-type avoidance box. Psychonomic Science, 1966, 5, 361-362.

BEECROFT, R. S., \& BOUSKA, S. A. Acquisition of avoidance running in the rat. Psychonomic Science, 1967, 9, 163-164.

BRUSH, F. R. On the differences between animals that learn and do not le arn to avoid electric shock. Psychonomic Scienœ, 1966, 5, 123-124.

KOSTANEK, D. J., \& SAWREY, J. M. Acquisition and extinction of shuttlebox with complex stimuli. Psychonomic Science, 1965, 3, 369-370.

LEVIS, D. J. Implosive therapy: The subhuman analogue, the strategy, and the technique. In S. G. Armitage (Ed.), Behavior modification techmiques in the treatment of emotional disorders. Battle Creck. Michigan: V. A. Publication, 1966.

McCLEARY, R. A. Response-modulating functions of the limbic system: Initiation and suppression. In E. Stellar \& J. M. Sprague (Eds.), Progress in physiological psychology. New York: Academic Press, 1966.

MILLER, N. E. Experimental studies of conflict. In J. McV. Hunt (Ed.), Personality and the behavior disorders. Vol. 1. New York: Ronald Press. 1944.

MOYER, K. E., \& CHAPMAN, J. A. Effect of continuous vs. discontinuous shock on shuttle box avoidance in the rat. Psychonomic Science, 1966, 4, 197-198.

MOYER, K. E., \& KORN, J.H. Effect of UCS intensity on the acquisition and extinction of an avoidance response. Joumal of Experimental Psychology, 1964, 67, 352-359.

OLTON, D. S., \& ISAACSON, R. L. Importance of spatial location in active avoidance tasks. Journal of Comparative \& Physiological Psychology, 1968, 65, 535-539.

TENEN, S. S. An automated one-way avoidance box for the rat Psychonomic Science, 1966, 6, 407-408.

THEIOS, J. Simple conditioning as two-stage all-or-none learning. Psychological Review, 1963, 70, 403-417.

THEIOS, J., \& DUNAWAY, J. E. One-way versus shuttle avoidance conditioning. Psychonomic Science, 1964, 1, 251-252.

NOTE

1. Supported in part by Public Health Service Research Grant No. 5 RO1 MH11734-04 to Judson S. Brown.

\title{
A photoelectric sound-activated relay
}

\section{ROBERT ADAMSON and LEVIE McNAB, FLORIDA ATLANTIC UNIVERSITY, Boca Raton, Fla. 33432}

By activating photocell control circuits by a low voltage lamp in parallel with speaker outputs on conventional recorders, it is possible to obtain reliable and inexpensive program capability.

For purposes of coupling relay activation with amplified sound pulses, it is possible to use the voltage generated across the speaker output of the source. This, of course, varies depending on degree of amplification; however, recordings of a human voice (approximately $60 \mathrm{~dB}$ ) from two sources (a Nurelco tape recording and an Audograph record) yielded voltages up to 4 across speaker terminals. These could easily have been exceeded with increased amplification during recording.

Although voltages in this range could be amplified, in turn, to operate standard relays, the same effect may be reached by the interposition of a low voltage lamp and a photocell in the circuit.

Selection of lamp voltage is arbitrary, although it should not be grossly exceeded by the output voltage generated by the sound. If recordings are made at low level, with little ambient noise. the output voltage will be correspondingly low. In any event, it is possible to measure the peak output after recording and to choose a lamp of roughly corresponding voltage. The device described here used a standard 3-V flashlight lamp, in parallel with an 8-ohm speaker (not necessary unless sound is desired).

The function of the lamp is simply to activate a photocell that controls the relay circuit. Fig. 1 shows the photocell placed in series with the control relay. The RCA SQ 2521 photocell has a light resistance of $350 \mathrm{ohms}$, and is rated at $250 \mathrm{~V}$ ac or dc, $20 \mathrm{~W}$ demand, or $0.2 \mathrm{~W}$ continuous. The control relay is a Sigma 97638, SPST $115 \mathrm{~V}$ ac, with a 5000-ohm coil. This imposes a rating of about $.06 \mathrm{~W}$ on the cell. Other relays may be used if different functions are desired. For example, with a latching relay, such as the Potter and Brumfield GM 11AL11, one pulse might be used to close the circuit, and the next pulse to open it. Such relays may also be used for flip-flop application. The cited relay need not be on continuously and, hence, would not exceed the power rating of the cell.

The lamp and photocell are enclosed in a light-tight box that prevents triggering of the circuit by ambient light.

With a conventional four-track tape recorder, e.g., the Norelco 401 , it is possible to program two relays by recording sound pulses on Tracks 1 and 3 , or 2 and 4 , and playing back on stereo to two speaker outputs. This technique allows the use of basic logic programs, such as OR, AND, and holding circuits. It also makes it possible to cue visual presentations on one track along with audio on the other.

Within the ranges tested, that is, a $2 . \mathrm{V}$ to $5 . \mathrm{V}$ output from the speaker terminals, introduction of the lamp caused a voltage drop of approximately $25 \%$. With impedance matching of the sound source and the speaker, sound attenuation was not excessive ( $5 \mathrm{~dB}$ from a top of $95 \mathrm{~dB}$, sound pressure level). Changes in lamp resistance as a result of heating had no material effect. Thus, if it is desired to keep the speaker in the circuit, simultaneous relay keying and audio presentation is feasible.

The circuit, excluding the sound source, is inexpensive (less than $\$ 10.00$ ) and reliable.

\section{NOTE}

1. This research was supported by the Air Force Office of Scientific Research, Grant No. 1163-66.

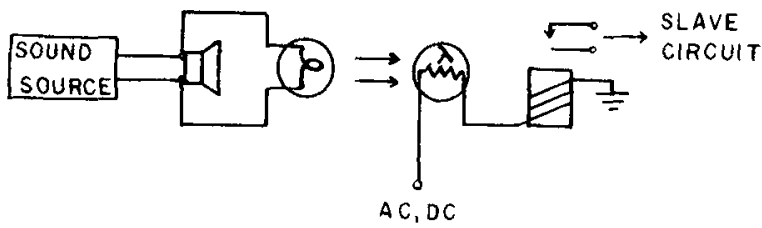

Fig. 1. Basic activation circuit with speaker included. 